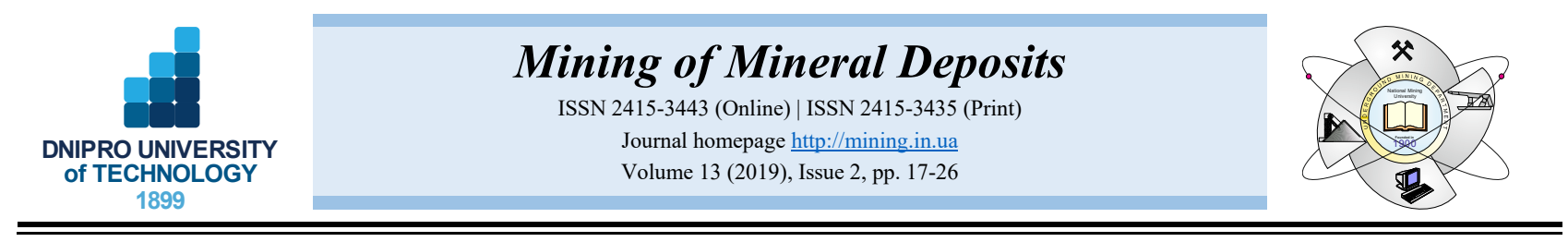

UDC 622.831

https://doi.org/10.33271/mining13.02.017

\title{
LABORATORY STUDIES OF A HIGH-STRENGTH ROOF BOLTING BY MEANS OF SELF-EXTENDING MIXTURES
}

\author{
I. Sakhno ${ }^{1 *}$, S. Sakhno ${ }^{1}$, O. Isaienkov², D. Kurdiumow ${ }^{3}$ \\ ${ }^{1}$ Donetsk National Technical University, Pokrovsk, Ukraine \\ ${ }^{2}$ Industrial Institute of the Donetsk National Technical University, Pokrovsk, Ukraine \\ ${ }^{3}$ Company of Mining and High-Altitude Work "AMC", Wieliczka, Poland \\ *Corresponding author: e-mailsahnohuan@gmail.com, tel.+380501659852
}

\begin{abstract}
Purpose is to analyze parameters of a new method to fasten roof bolts with the help of nonadhesive mixtures extending while hardening along with the development of high expansion pressures.

Methods. The research, concerning forces applied while fastening roof bolts by means of self-extending mixtures, has been carried out under full-scale laboratory conditions using pressing-in method. Rock mass was simulated by means of concrete in plastic and metal forms, and steel pipes. The latter simulated ultimate rigidness conditions. Roof bolts were simulated by means of reinforcement steel fragments. In the context of the research, bolt diameters varied from 8 to $32 \mathrm{~mm}$, and borehole diameters varied from 26 to $43 \mathrm{~mm}$. Hydraulic 50-ton press was used for the tests. The testing results were applied to obtain regressive dependences of bolt fastening efforts in terms of different ratios between roof bolt diameter, borehole diameter, and incapsulation depth. Mine experiments concerning efforts to fasten Rockbolt System AG roof bolts of J64-27 type to strengthen chamber 1 of level 3 in Velychka mine were performed using a method of static bolt extraction. Hydraulic extraction device was equipped by ZEPWN CL 18T sensor and CL 162z-DW recorder.

Findings. It has been proved experimentally that operation mechanism of the roof bolts, fastened by means of selfextending mixtures during hydration hardening, is close to the modern energy absorbing bolts. Bolt diameterborehole diameter ratio range, when ultimate effort of bolt fastening by means of extending mixtures is achieved, has been determined. Functional connection between the efforts to fasten roof bolts, using extending mixtures, and diameters of borehole and the roof bolt has been identified as well as linear connection between incapsulation depth and bearing capacity of the roof bolt.
\end{abstract}

Originality. A new concept to fasten roof bolts with the help of nonadhesive technique owing to their quazistatic compression between borehole walls, taking place as a result of hydration self-extension of mixtures which can achieve $30-50 \mathrm{MPa}$ pressures under the conditions of zero deformations, has been developed. Regularities in the variation of efforts to fasten bolts, using the technique, depending upon roof bolt - fastening mixture - rock mass system geometry have been determined.

Practical implications. The results can be used to calculate parameters of roof bolting with high bearing capacity under the conditions of large deformations. The proposed fastening method may be implemented in mine workings.

Keywords: roof bolt, fastening of roof bolts, adhesion, rocks, stresses

\section{INTRODUCTION}

Roof bolting of underground mine workings are popular in coal mines and ore mines worldwide (Windsor, 1997; Wen, 2010). History of such a support use for underground mine workings lasts for almost a century. During the period, roof bolting systems have experienced their evolution. According to their operation principle, modern roof bolts may be divided into five basic catego- ries: hanging; lacing; reinforcing of fissured rocks, and block holding; supporting; and combined systems.

Rock hanging (i.e. anchoring) is based upon fastening soft rocks of immediate roof (since the rocks have tendency to slutting and breaking) to solid rocks of the main roof using anchors (Fig. 1a) (Habenicht, 1983; Windsor \& Thompson, 1993). In this context, roof locking bolts with point fastening were mainly considered.

(C) 2019. I. Sakhno, S. Sakhno, O. Isaienkov, D. Kurdiumow. Published by the Dnipro University of Technology on behalf of Mining of Mineral Deposits. This is an Open Access article distributed under the terms of the Creative Commons Attribution License (http://creativecommons.org/licenses/by/4.0/), which permits unrestricted reuse, distribution, and reproduction in any medium, provided the original work is properly cited. 
(a)

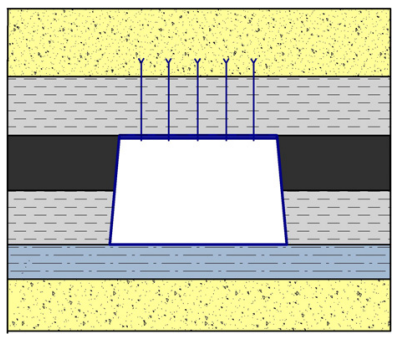

(c)

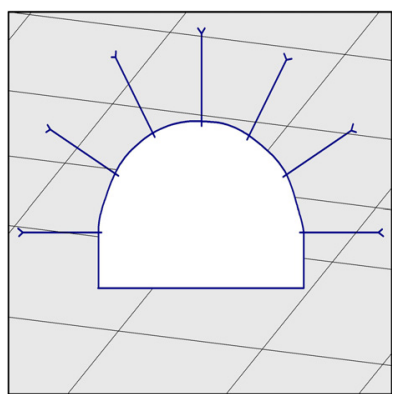

(b)

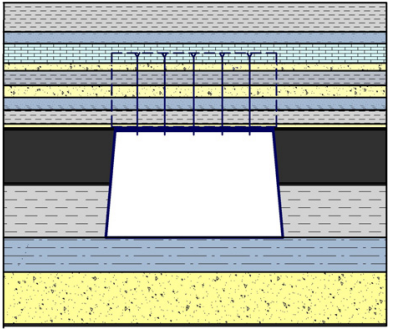

(d)

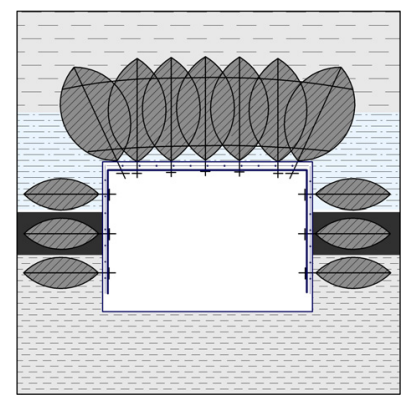

Figure 1. Structural schemes of anchors: (a) rock hanging; (b) lacing; (c) reinforcing of fissured rocks; (d) supporting anchoring

Such an approach can be implemented if only a layer of solid rocks is available over unstable layer within the anchor bolt length; the fact narrows its application area radically. Under the conditions of the current depth of coal mines even solid rocks break with time due to the formation of areas of nonelastic deformations; the fact prevents from rock hanging implementation.

Lacing concept (i.e. composite beam) (Fig. 1b) relies upon formation of a single load-bearing structure by a type of a composite beam or a plate (Windsor \& Thompson, 1993). It is formed from separate rock layers having different strength degrees with the help of their anchoring. Generally, mechanical anchors with point fastening and possibility to be lengthened are selected.

Methods to calculate anchoring in the process of lacing of layers are based upon laws of structural mechanics applied for continuous isotropic bodies only. As it is known, rocks are not such bodies. Formation of a zone of nonelastic in the neighbourhood of a mine working is not taken into consideration. The fact can explain mismatch between calculation results and experimental results.

Reinforcing of fissured rocks, and block holding (Fig. 1c) can be implemented with the help of individual anchors as well as anchoring (Nilsen \& Palmstrom, 2000). In this context, basic function of anchors is to retard the development of available fissures and to prevent from formation of new ones. If fissures are available, then rocks break with the formation of blocks with different shapes. In terms of such a variant, anchors with chemical bonding are generally used since they have to prevent blocks from their displacement towards a mine working. The approach has been analyzed thoroughly with the help of experiments (Alexander \& Hosking, 1971).

A concept of supporting anchoring (Fig. 1d) has been developed by scientists and researches of the Institute of Geotechnical Mechanics named by N. Poljakov of Na-

tional Academy of Sciences of Ukraine (Dnipro, Ukraine). Its idea is as follows: a system of highly reliable supports, blocking rock displacements within a mine working, is developed within a border rock mass with the help of chemically bonded anchors having high degree of bearing capacity (i.e. $250-110 \mathrm{kN}$ ) (Bulat \& Vinogradov, 2002). In this context, supports from anchor reinforced rocks are immovable ones having possibility to move towards mine working only owing to elastic deformations of anchor bolts. In the neighborhood of the anchors, rock blocks are compressed; they cannot experience lamination thus having high bearing capacity. The idea has been included in anchoring standards developed by Institute of Geotechnical Mechanics named by N. Poljakov of National Academy of Sciences of Ukraine.

Recently, systems of two-level support has become popular; essentially, they are combination of lacing technique with other ones (Hyett, Bawden, \& Reichert, 1992; Pells, 2002). Its implementation concept is as follows: short anchors, being as a rule rigid reinforced polymeric ones, support border rocks; long anchors, being as a rule flexible anchors, "lace" the reinforced area up to the undisturbed rock mass (Fig. 2). General view of the most popular anchors is represented in Fig. 2 (Satola \& Hakala, 2001). Combined anchoring systems are rather advantageous but need specific equipment for drilling and anchor mounting.

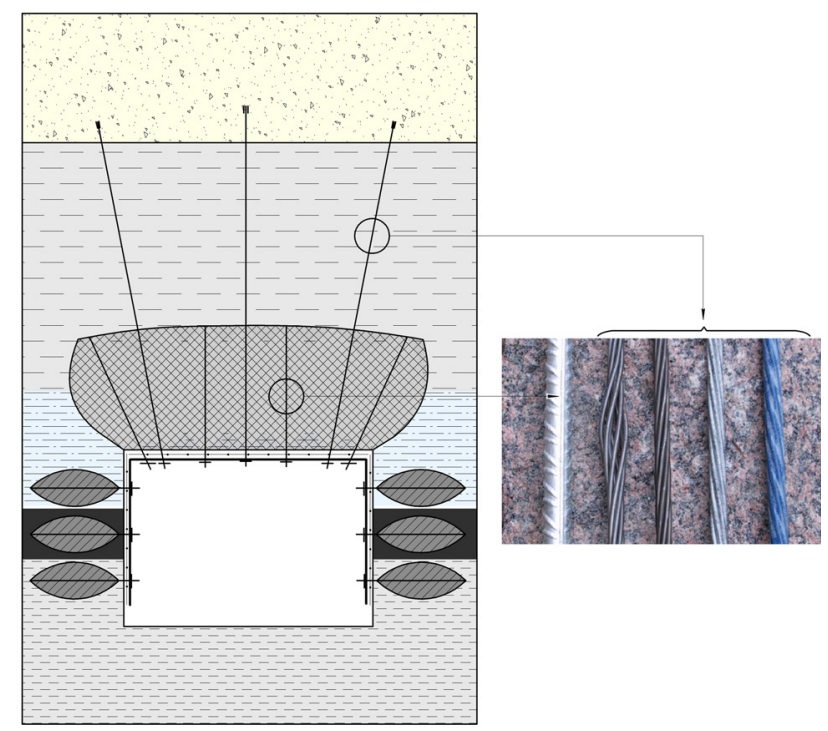

Figure 2. Structural scheme of the combined two-level anchoring

Traditionally, the schemes are implemented using anchors of the three types:

- with local (i.e. point), generally mechanical fastening (Li, Stjern, \& Myrvang, 2014; Korzeniowski, Skrzypkowski, \& Zagórski, 2017);

- with chemical bonding being applied generally along the whole length of the bolt (i.e. adhesive ones) (Li, Stjern, \& Myrvang, 2014);

- anchors which operation is based upon friction principle (i.e. frictional ones) (Li, Stjern, \& Myrvang, 2014).

The listed anchors have operational disadvantages preventing them from retarding significant lamination of highly resistive rocks (Sakhno, Sakhno, Kurdiumow, \& 
Shvets, 2018). Adhesive anchors, being of high bearing capacity, cannot take up large deformation typical for deep mines. As for the frictional anchors, they can operate under significant deformation; however, their bearing capacity is insufficient. Hence, the current anchoring tendencies are intended to develop energy absorbing bolts (Li, 2011; Li, Stjern, \& Myrvang, 2014). Fundamental advantage of such systems is to provide high bearing capacity under significant deformations. Their disadvantages are complicated design and high production cost.

In the context of coal mines, extracting seams at great depth, development of anchor system which would have high bearing capacity and make it possible to preserve stability of mine workings in terms of considerable lamination of rocks within border area, is topical research and practice problem which solution is considered in the research.

\section{THE RESEARCH METHODS}

The authors have developed the idea of nonadhesive fastening of roof bolts (Sakhno, Sakhno, Kurdiumow, \& Shvets, 2018) according to which a bolt is anchored at the expense of its compression along the whole length of a borehole with the help of mixtures extending in the process of hydration hardening.

Operation of anchors, fastened by means of such mixtures, was analyzed under laboratory conditions. Experiments were full-scaled.

Profiled steel bolts are the most popular for chemical bonding; thus, in the process of the research, anchors were simulated by means of reinforced steel rods. Many studies of bolt design (i.e. height, spacing, reinforcing angle) concerned the problem (Yokota et al., 2018); thus, the problems were not considered in the paper and standard armature was used.

To determine effect of deformation characteristics of rocks on the quality of anchor fastening, during stage one of experiments the rocks were simulated by means of concrete filled in steel pipes (Fig. 3a); during stage two plastic two were used (Fig. 3b). During stage three steel pipes simulated rocks which diameters were equal to a borehole diameter (Fig. 3c). Thus, increase in the rock mass rigidness was simulated as follows: concrete filled in plastic form; concrete filled in steel form; and steel tube.

In the context of the experiments, armature diameter varied from 8 to $32 \mathrm{~mm}$; borehole diameter varied from 26 to $43 \mathrm{~mm}$. Minimal statistically required number of experiments was calculated for each of the series. Classical Bienaymé-Chebyshev inequality has been applied. Thus, for the experiments with concrete samples in plastic tube and metal tube, borehole diameter had two amounts: 32 and $43 \mathrm{~mm}$; anchor diameter had by five amounts (i.e. 12, $18,22,26$, and $30 \mathrm{~mm}$; and 12, 18, 22, 26, and $30 \mathrm{~mm}$ respectively). Each of the experiments was carried out three times. The experimental results were used as a basis to calculate statistical characteristics.

According to Bienaymé-Chebyshev inequality, the number of experiments can be calculated with the help of the dependence (Kolmogorov \& Fomin, 1957):

$P[|\bar{x}-M(x)| \leq \varepsilon] \leq 1-\frac{D(x)}{n \cdot \varepsilon^{2}}$, where:

$n$ - the number of the carried-out experiments;

$\bar{x}$-average value of $x$ amount which is measured randomly during the experiment;

$M(x)$-mathematical expectation of $x$ amount; $\left(M(x)=\lim _{n \rightarrow \infty} \bar{x}\right)$;

$D(x)$ - dispersion of amount $x$ calculated according to the results of $n$ experiments;

$\varepsilon-$ the result accuracy.

(a)

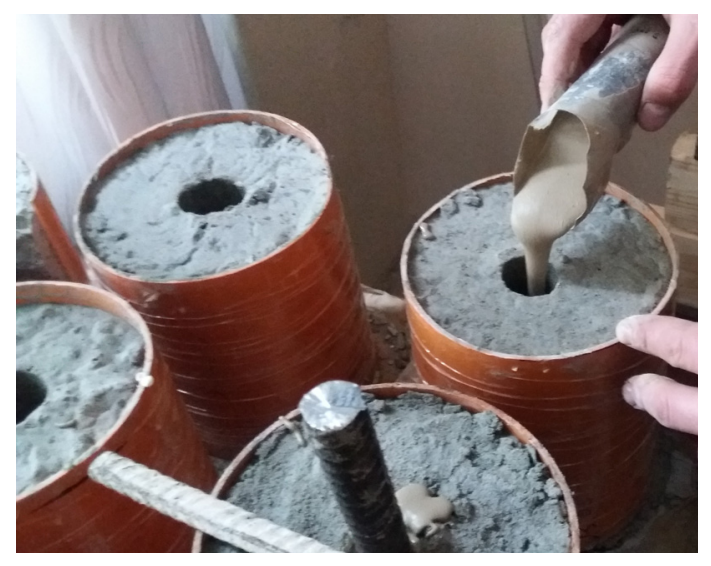

(b)

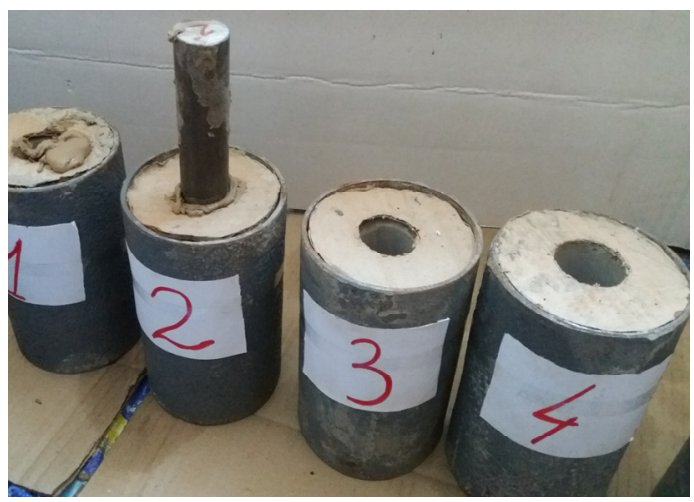

(c)

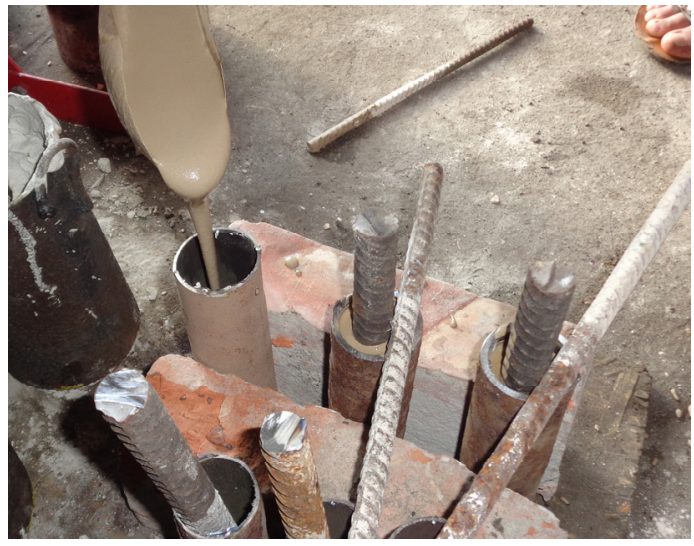

Figure 3. Mounting of anchor, fastened by means of a mixture extending while hardening, in the models simulating rocks: (a) with the help of concrete in a plastic form; (b) with the help of concrete in a metal form; (c) with the help of steel pipes 
Hence, $n$ is:

$$
n \geq \frac{D(x)}{\varepsilon^{2}\left(1-P_{d}\right)},
$$

where:

$P_{d}$ - confidential interval being 0.95 .

Following values of efforts, applied for $F$ anchors fastening, have been obtained as a result of previous tests: $77.0,75.9$ and $78.1 \mathrm{kN}$.

$$
\begin{aligned}
& \bar{x}=\frac{\sum x_{i}}{n} ; \\
& D=\frac{\sum_{i=1}^{n}\left(x_{i}-\bar{x}\right)^{2}}{n-1} .
\end{aligned}
$$

For instance, if it is required to calculate the number of tests if borehole diameter is $32 \mathrm{~mm}$, and bolt diameter is $26 \mathrm{~mm}$ for concrete samples in a metal form, $D=1.09$ in terms of $3 \%$ accuracy to be rational for comparative research, $n \geq 4.62$.

Hence, 5 is that required number of each test imitations for the mentioned accuracy.

The experiments were carried out as follows. Plastic foam was placed into a bottom part of the holes simulating boreholes. Depth was $50 \mathrm{~mm}$. Then, fastening mixture was added and anchor bolt was mounted. Bolt height above a sample was $100 \mathrm{~mm}$. After hardening, plastic foam was taken away. The samples were loaded on the press until complete $50 \mathrm{~mm}$ sinking of the bolt with incremental registration of efforts and deformations.

Series of experiments were carried out to determine the effect of incapsulation depth on the anchor fastening; length of anchor fastening varied from 8 to $15 \mathrm{~cm}$. Concrete samples in metal form were used; hole diameter was $32 \mathrm{~mm}$, diameter of bolts was $18 \mathrm{~mm}$, and their length was $20 \mathrm{~cm}$. The bolts were made of smooth round mill products. The experiment schedule coincides with the previous one. Figure 4 demonstrates general view of the models as well as results.

Full-scale studies concerning efforts of fastening of Rockbolt System AG anchors of J64-27 type were performed in a chamber 1 of level 3 in Wieliczka mine (Poland). Standard technique of statistic pulling of bolts has been applied (Fig. 5). Hydraulic device for the pulling has been equipped with ZEPWN CL 18T sensor, and CL 162z-DW recorder.

\section{RESULTS AND DISCUSSION}

Figure 5 explains operation schedule of rock bolts fastened by means of extending mixtures. Pressure, resulting from the mixture expansion, holds the bolt in a borehole. Progress of a zone of nonelastic deformations in the neighbourhood of mine workings results in fissure development in turn factoring into rock lamination and bolt loading. After ultimate load is achieved, anchor slides within the borehole with conditionally constant friction resulting from friction forces between the hardened extending mixture, and the bolt (Fig. 6).

(a)

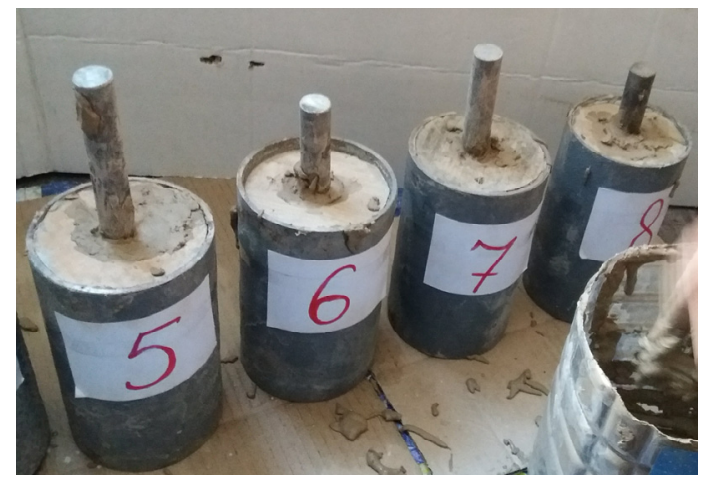

(b)

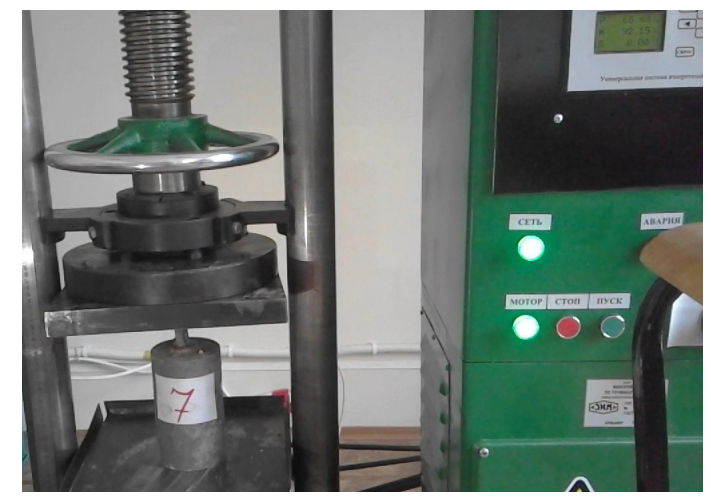

Figure 4. Models to study fastening depth effect on the bearing capacity of anchor system (a); general view of the experiment (b)

(a)

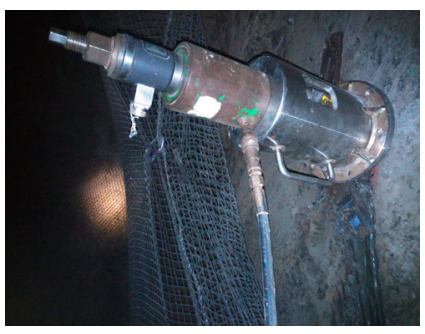

Figure 5. Device for pull-tests of bolts: (a) pulling device with loading sensor; (b) hydraulic pump
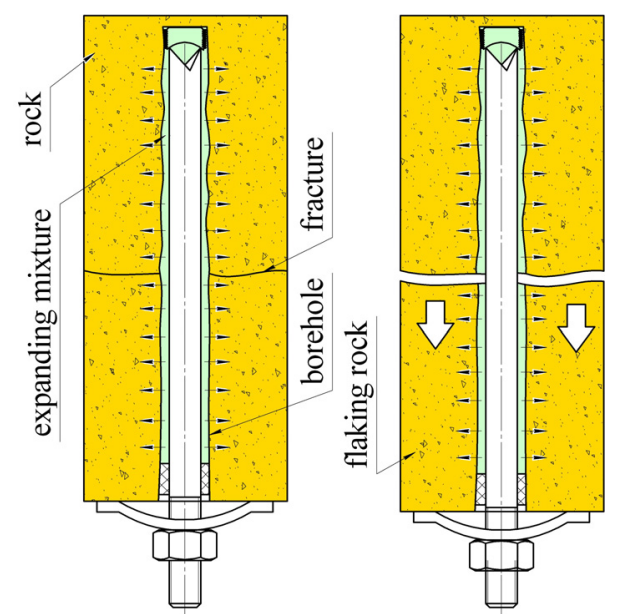

Figure 6. Scheme of "bolt - extending mixture - rock" system 
Characteristics of the fastening extending mixture have been determined before and experiments were carried out earlier; the results have been published in paper (Sakhno, Sakhno, Kurdiumow, \& Shvets, 2018). It has been determined that the support is of two-stage operation. First, anchor takes load in a rigid mode, then in a flexible mode; resistance is more or less constant (Fig. 7).

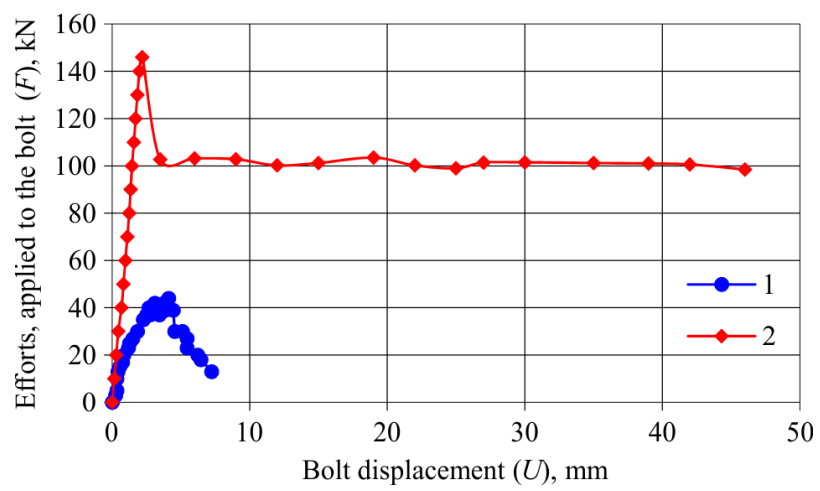

Figure 7. Load-deformation dependence graphs in the contexts of the tests: 1 -bolts fastened using Cement $K L ; 2$ - bolts fastened using extending mixtures

According to the experimental results concerning anchors, made of the reinforced steel, bearing capability of the system was $188.11 \mathrm{kN}$ in terms of a rigid mode, and $157.50 \mathrm{kN}$ in a flexible mode when fastening length was $10 \mathrm{~cm}$. In the context of a rigid mode, deformations were 2.2 and $50.0 \mathrm{~mm}$ in the context of a flexible mode. The effort, applied to fasten bolts with the help of Cement KL (Orica) mixture, selected as a basic variant of adhesive bond to compare, was $44.0 \mathrm{kN}$ and deformation was $4.1 \mathrm{~mm}$.

The experiment confirms that the developed support system makes it possible to prevent from large deformations of border rocks in terms of high resistance favouring the increased stability of mine workings.

Experiments with different anchor diameter - borehole diameter ratios have been carried out to determine features of anchor system operation while varying geometry of anchor-extending mixture-rock system and to identify rational parameters of the technique to obtain ultimate bearing capacity of the system.

Since the form, made of plastic pipes, is of insignificant strength, the majority of samples within the form were deformed before press tests due to mixture expansion. Different-size fissures were formed within the samples depending upon the mixture amount and borehole diameter (Fig. 8). Certain share of the samples was crushed together with their forms.

The fissured samples, where forms were not crushed, were tested using a press in accordance with the abovementioned loading schedule. Figure 9 demonstrates results of the tests.

Results of the experiments have helped determine the following: if anchor diameter - borehole diameter ratio (i.e. $d / D$ ) was less than 0.36 , concrete samples in plastic forms were crushed internally; the concrete had open fissures; thus, it was impossible to carry out the tests. In the context of samples, where fissures were closed, ultimate effort to fasten anchors was $19-35 \mathrm{kN}$.

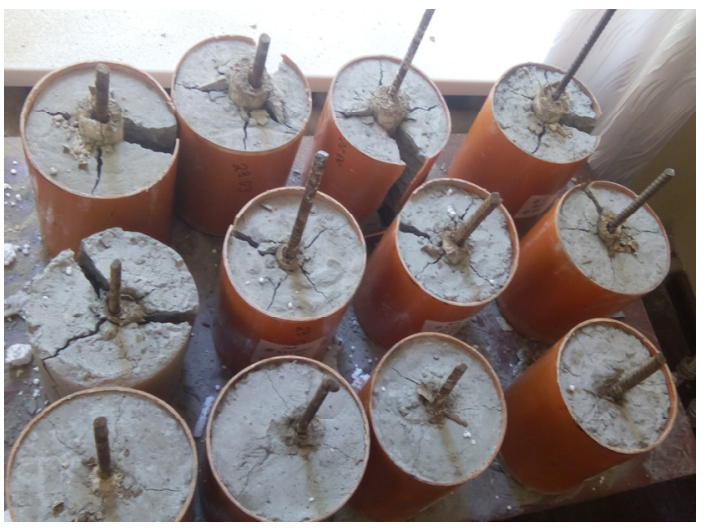

Figure 8. Samples in plastic forms after the mixture expansion

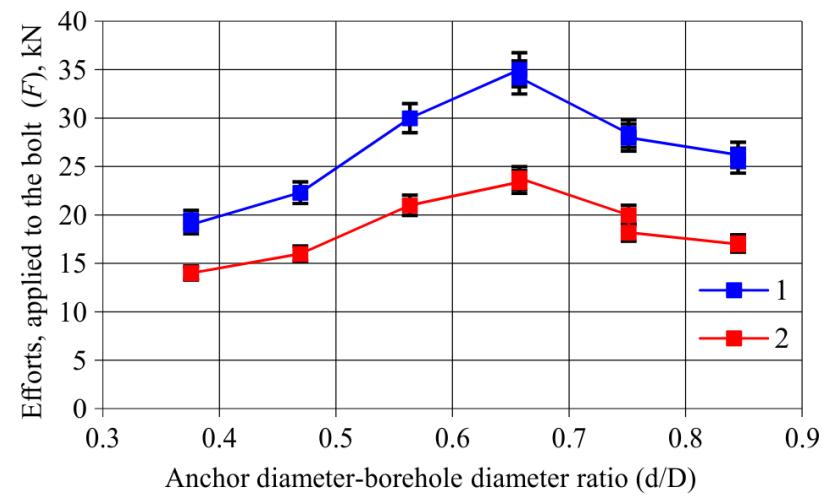

Figure 9. Dependence graphs of efforts, applied to bolt fastening, upon anchor diameter d-borehole diameter $D$ ratio: 1 - rigid mode (i.e. ultimate fastening effort); 2 -flexible mode (i.e. average fastening effort)

After the bolt was transited to flexible mode, the effort decreased by $35-45 \%$; however, it remained within $14-24 \mathrm{kN}$. Area of ultimate bearing capacity was limited by $0.55-0.75 d / D$ ratio.

To identify real pressures, under which concrete samples in plastic forms were crushed, laboratory experiment has been carried out. $100 \mathrm{~mm}$ cylindrical samples with 32 and $43 \mathrm{~mm}$ holes, filled with extending mixtures, were placed between press plates (Fig. 10a). (a)

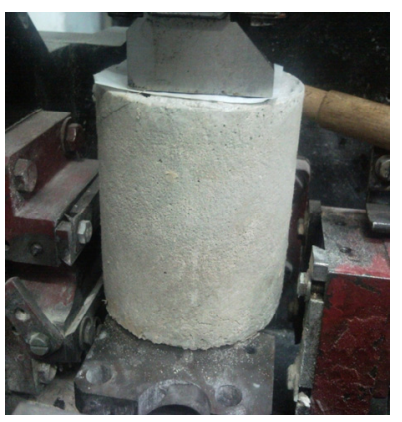

(b)

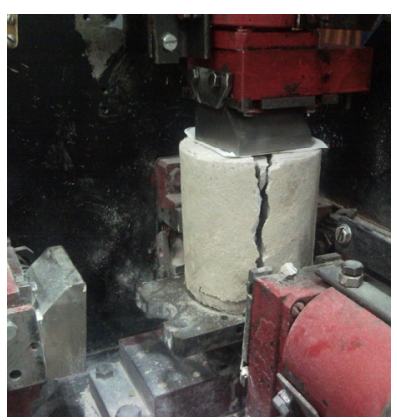

Figure 10. General view of the experiment: (a) before the sample was crushed; (b) after the sample was crushed

Laboratory temperature was $20^{\circ}$. Mixture expansion resulted in the increased pressure on the vertical press plate as well as on walls of the holes (Fig. 10a). Load increase in time was recorded by the press sensors. In 
this context, vertical deformations were kept as those close to zero. Value of pressures, under which the sample experienced its crush, was critical (Fig. 10b). After updating the obtained results per mixture surface area within the borehole, dynamics of increase in real mixture pressures was determined (Fig. 11). If borehole diameter is $32 \mathrm{~mm}$, then $7.6 \mathrm{MPa}$ pressures are failure ones. If borehole diameter is $43 \mathrm{~mm}$, then $3.8 \mathrm{MPa}$ pressures are failure ones. It is obvious that pressure increase dynamics depends upon anchor diameter in a borehole; however, in this context critical pressure value remains invariable for a borehole having certain diameter.

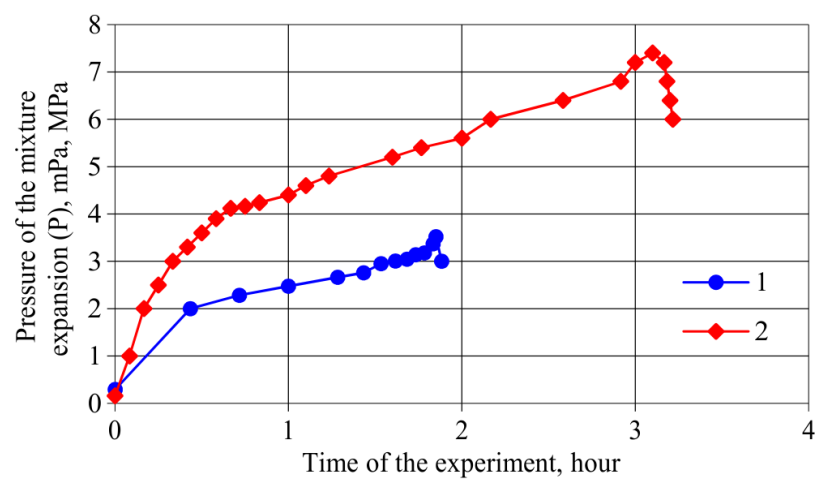

Figure 11. Graphs of the extending mixture pressure increase: 1 -diameter of a hole simulating borehole, $43 \mathrm{~mm} ; 2-32 \mathrm{~mm}$ hole diameter

Figures 12 and 13 demonstrate results of experiments with concrete samples in steel pipes and when steel pipes simulated rocks. Figure 14 explains state of the bolts after the experiment.

Hydration pressures of self-extending mixture under the conditions, being close ultimately to perfectly rigid ones, have been obtained as a result of tests carried out with the plasticized mixture using a device of triaxial compression when deformations along the three axes were kept in zero (Sakhno \& Molodetsky, 2013).

Analysis of graphs, represented in Figure 12, shows that the area of ultimate bearing capacity in the tests with concrete pipes does not coincide with analogous area recorded in the tests with concrete samples in plastic pipes. Effective range is limited by $0.55-0.85 d / D$ ratio, i.e. it is shifted towards one. Absolute fastening values are quite larger. Thus, ultimate efforts to fasten bolts achieve $80 \mathrm{kN}(d / D=0.76)$ and $100 \mathrm{kN}(d / D=0.81)$ for 32 and $43 \mathrm{~mm}$ borehole diameters respectively. Efforts, which kept anchor during displacement (flexible mode), were 42.0 and $64.8 \mathrm{kN}$ for 32 and $43 \mathrm{~mm}$ borehole dia-meters respectively. The obtained bearing capacity of the modeled system is typical for $150 \mathrm{~mm}$ length of anchor fastening, and $50 \mathrm{~mm}$ ultimate deformation.

The experiments were carried out in terms of the most rigid mode in steel pipes, demonstrated greater values of bearing capacity (Fig. 13). Thus, ultimate recorded bearing capacity for $26 \mathrm{~mm}$ borehole diameter was $119 \mathrm{kN} \quad(d / D=0.76), 112 \mathrm{kN} \quad(d / D=0.57)$ for $32 \mathrm{~mm}$ borehole diameter, and $153 \mathrm{kN}(d / D=0.55)$ for $43 \mathrm{~mm}$ borehole diameter. (a)

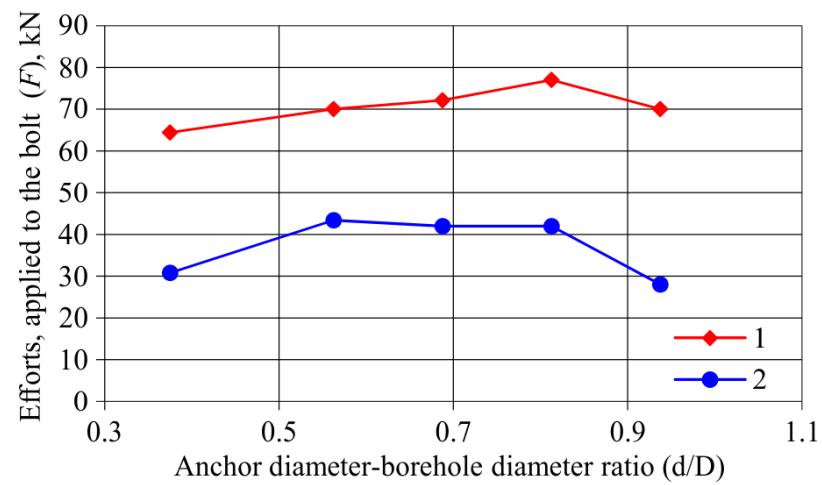

(b)

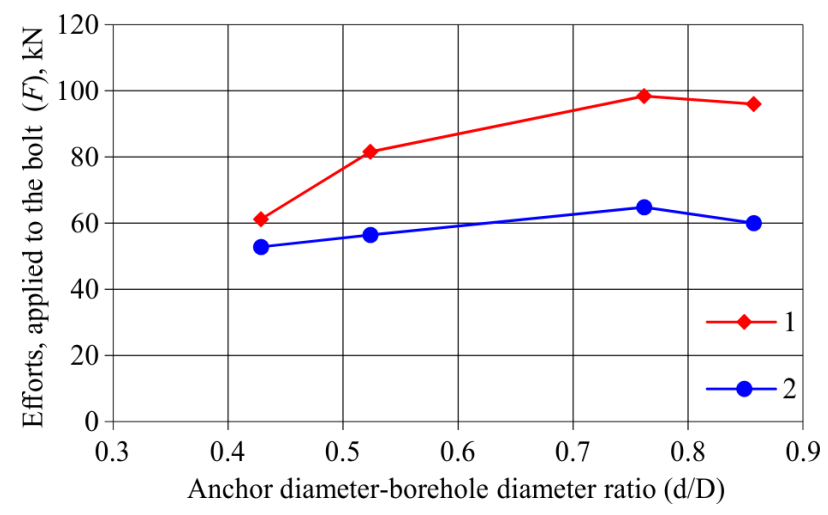

Figure 12. Dependence graphs of efforts, applied to bolt fastening, upon anchor diameter d-borehole diameter $D$ ratio: (a) $d=32 \mathrm{~mm}$; (b) $d=43 \mathrm{~mm} ; 1$-rigid mode (i.e. ultimate fastening effort); 2 -flexible mode (i.e. average fastening effort)

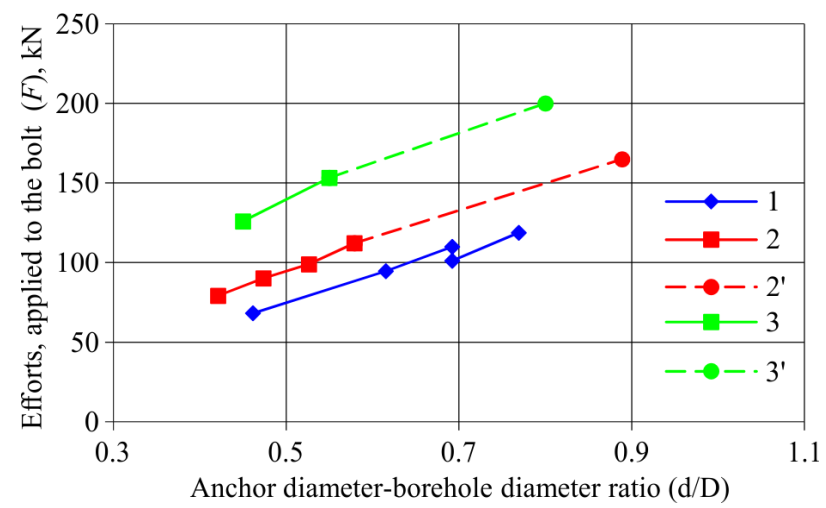

Figure 13. Dependence graphs of ultimate effort, applied to fasten bolts, upon anchor diameter-borehole diameter ratio: 1 -borehole diameter is $26 \mathrm{~mm}$; 2 -borehole diameter is $32 \mathrm{~mm}$ (2 is armature bend); 3 -borehole diameter is $43 \mathrm{~mm}$ (3 is armature bend)

However, in this case, the ultimate recorded bearing capacity is not absolute bearing capacity depending on the fact that in the context of some experiments bolt did not move inside a pipe but bended (Fig. 14). In such cases, it was impossible to record starting point of the bolt bend. Hence, strictly speaking, it is impossible to come to conclusion upon potential bearing capability. 


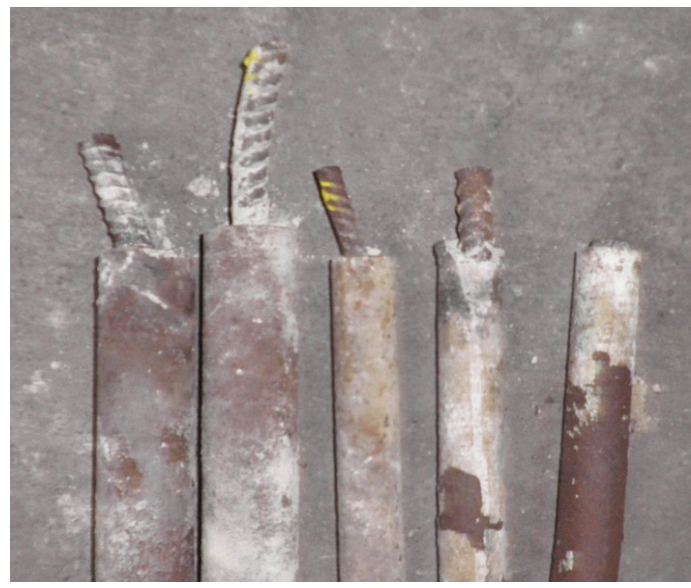

Figure 14. General view of the samples after the experiment

Dash line in Figure 13 explains predicted values of bearing capacity. It has been determined experimentally, that under the conditions, close to rigid ones, pressure of extending mixture becomes $35-38 \mathrm{MPa}$ after 12 hours of hydration process start. Under such pressures, anchor does not slip within a borehole; thus, it is impossible to measure fastening efforts.

It has been determined experimentally, that under the conditions, close to rigid ones, pressure of extending mixture becomes $35-38 \mathrm{MPa}$ after 12 hours of hydration process start. Under such pressures, anchor does not slip within a borehole; thus, it is impossible to measure fastening efforts.

It is understood that such a result is stipulated by imperfect experimental schedule. In-site anchor experiences its extension rather than compression. Accordingly, either ultimate share strength of fastening mixture or ultimate yield strength of anchor would be critical rather than bend as it was recorded in the tests. Moreover, under actual conditions, bolt experiences is expansion; hence, its diameter decreases and real values of bearing capacity are less to compare with those obtained experimentally where bolts becomes thicker while compressing. Nevertheless, despite the fact it is quite obvious that bearing capacity of anchor-fastening mixture-rock mass system varies according to certain regularities which to the first approximation can be formulated basing upon the experiments.

Analysis of the results has helped determine $d / D$ ratio range in terms of which fastening of rock bolts by means of extending mixtures is ultimate while hardening. Hence, for samples with closed fissures (i.e. concrete samples in plastic forms) it is $0.55-0.75$, and it is $0.55-0.85$ for tougher conditions. In the context of case one, efforts to fasten anchors within $32 \mathrm{~mm}$ diameter boreholes achieves $20-35 \mathrm{kN}$ depending upon diameter of anchors under the pressure of extending mixture being almost $7.5 \mathrm{MPa}$. In case two, efforts to fasten anchors achieve $80-100 \mathrm{kN}$ depending upon $d / D$ ratio. In this context, extending pressure of fastening mixture achieves $35-38 \mathrm{MPa}$. When decrease in $d / D$ ratio is less than 0.55 , fastening mixture turns out to be a weak component within the fastening system since it becomes too thick.
Axial load of the bolt results in shear stresses exceeding ultimate shear strength of the mixture provoking armature slip. Increase in $d / D$ ratio of the abovementioned values factors into the decreased mixture amount and, subsequently, pressure relief developed by it; thus, minor effort for anchor fastening takes place.

The obtained results have been used to determine functional dependence of anchor fastening effort upon the fastening system geometry being anchor diameter borehole diameter ratio, and length of anchor fastening within a borehole.

To do that, statistical processing of the laboratory modeling results has been performed. SPSS package became the analysis tool. The analysis was separated for samples in plastic forms, and samples in concrete forms. PSS. Experimental results, concerning samples in metal pipes were not analyzed due to insufficient number of numerical results since the bolts bended during the tests.

In the context of each analysis, sampling involved 50 values. Borehole diameter $D$ and anchor diameter $d$ were selected as basic modeling data. The carried out correlation analysis made it possible to connect the indices. Matrix of corresponding pair correlation between the indices as well as basic statistical characteristics has been calculated with the help of SPSS.

Chaddock scale has been applied to evaluate correlation between the indices. Direct proportion is typical for each index. High correlation level is observed for $F-d$, pair of indices; correlation is significant at 0.01 level. Correlation of a mean level is typical for $F-D$ pair where significant level is 0.05 . Only $d-D$ pair is correlated weakly. However, such a correlation is not important physically for the research.

Regressive nonlinear analysis, carried out with the help of SPSS functional, has helped determine functional connection between the parameters. In terms of $R^{2}=0.879$ correlation coefficient, the connection is expressed with the help of function:

$F=52.51-0.05 D^{2}-0.12 d^{2}+0.19 D d$.

Similar calculations were performed for concrete samples in plastic forms. Regressive dependence $R^{2}=0.839$, obtained with the correlation coefficient, is:

$F=35.14-0.08 D^{2}-0.19 d^{2}+0.246 D d$.

For frictional type bolt (Li \& Håkansson, 2018), fastening effort is directly proportional to the fastened area length. To support such an effect in the process of bolt fastening with the help of mixtures, expanding while hardening, a number of experiments were carried out where length of anchor fastening varied from 8 to $15 \mathrm{~cm}$. Figure 15 demonstrates results of the experiments.

The experimental results show that linear connection between incapsulation depth and bearing capacity is preserved. It should be noted that if fastening length is 15 $\mathrm{cm}$, anchor bolt bended in terms of $123 \mathrm{kN}$ effort (Fig. 15); however, no displacement was observed. Hence, fastening effort exceeds bending effort. 
(a)
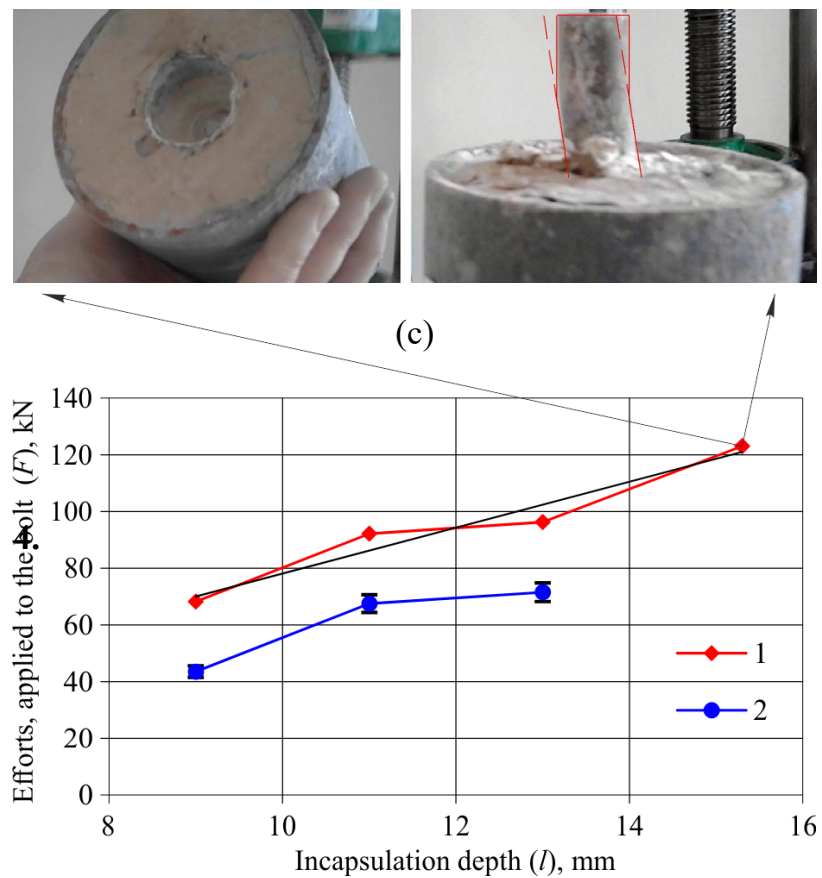

Figure 15. Dependence graphs of bolt fastening efforts upon incapsulation depth (a): 1 - rigid mode (ultimate fastening effort); 2 -flexible mode (mean fastening effort); (b) it is seen from the bottom part of the simulated borehole that free space is within the bottom part but the bolt does not displace; (c) anchor bolt bended during the experiment

Relying upon the abovementioned and taking into consideration (5) and (6) it is possible to conclude that anchor fastening effort under the conditions, being similar to the experiments with samples in metal form, i.e. under the conditions of continuous medium, and in terms of $35-38 \mathrm{MPa}$ mixture expansion as well as fastening length $l$ is:

$$
F=\left(52.51-0.05 D^{2}-0.12 d^{2}+0.19 D d\right) l \text {. }
$$

As for the bolt fastened under conditions, being similar to the experiments with samples in plastic forms, i.e. in a fissured rock mass, in terms of $3.8-7.6 \mathrm{MPa}$ expansion pressure and fastening length, effort is:

$$
F=\left(35.14-0.08 D^{2}-0.19 d^{2}+0.246 D d\right) l \text {. }
$$

The pressures, obtained under laboratory conditions and calculated on dependence 3 , to fasten bolts with the help of expanding mixtures exceed significantly minimally admissible values recorded in-site. For example, they are ten and more times more to compare with indices recorded in the context of pull-tests of Rockbolt System AG of J64-27 type (Fig. 16) carried out in chamber 1 of level 3 in Wieliczka mine (Poland).

Requirements for rock bolt fastening specify their $100 \mathrm{kN}$ load without slipping. In accordance with the abovementioned results, concerning anchor fastening with the help of self-expanding mixtures, they exceed such efforts significantly.

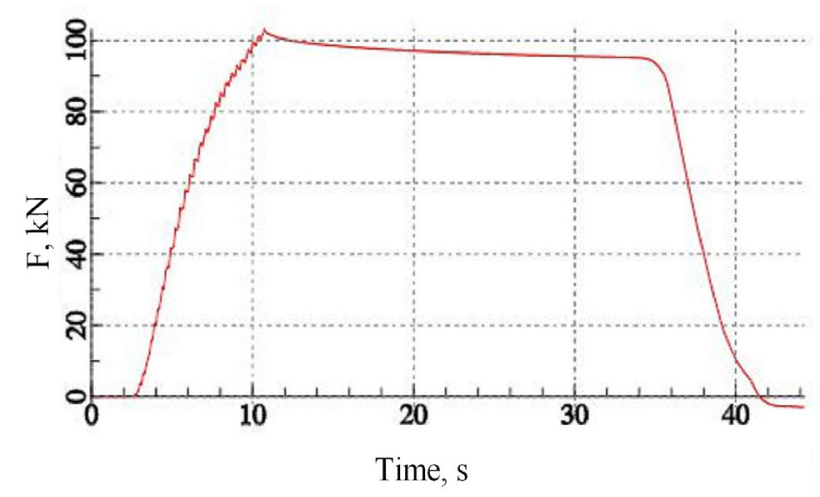

Figure 16. Testing results concerning quality of Rockbolt System AG J64-27

The obtained anchoring parameters correspond to the modern energy absorbing roof bolting systems (Li, 2011; Li, Stjern, \& Myrvang, 2014). Analysis of operation schedule of anchors, fastened with the help of expanding mixtures, confirms that mechanism of anchor-fastenerrock system is close to the modern energy absorbing bolts (He et al., 2014).

\section{CONCLUSIONS}

Innovative concept to fasten anchor bolts at the expense of their quazistatic compression between borehole walls resulting from hydration self-expansion of mixtures which can achieve $30-50 \mathrm{MPa}$ pressures under the conditions of zero deformations has been developed.

Laboratory modeling of anchor fastening in the pull-test mode have been carried out. Geometrical parameters varied. As a result of processing of the laboratory research results, anchor diameter - borehole diameter ratio has been determined in terms of which ultimate anchor fastening effort is achieved with the use of self-expanding mixtures. Regularities concerning effort variation of anchor fastening depending upon the geometry of anchor-fastening mixture-rock mass system as well as upon bolt incapsulation depth have been identified.

It has been determined that under the conditions, being close to absolutely rigid ones, bolt fastening efforts are so high that exceed critical bending anchor efforts. The pressures, obtained under laboratory conditions and calculated on the dependence 3 to fasten bolts with the help of expanding mixtures, exceed significantly minimum allowable efforts recorded in-site.

It has been demonstrated experimentally that in the context of hydration hardening, operating principle of anchor bolts, fastened with the help of self-expanding mixtures, is close to operating principle and performance capabilities of the modern energy absorbing bolts.

\section{ACKNOWLEDGEMENTS}

The authors of the paper express appreciation to the employees of ZGRiW "AMC" Company, operating at the territory of Kopalnia Soli "Wieliczka", for the research in-site support and materials provided. 


\section{REFERENCES}

Alexander, L.G., \& Hosking, A.D. (1971). Principles of rock bolting, formation of a support medium. Proceedings Symposium on Rock Bolting. International Journal of Rock Mechanics and Mining Sciences \& Geomechanics Abstracts, 11(2), A44.

https://doi.org/10.1016/0148-9062(74)92842-3

Bulat, A.F., \& Vinogradov, V.V. (2002). Roof bolting in mine workings of coal mines. Dnipropetrovsk, Ukraine: Institute of Geotechnical Mechanics of the National Academy of Sciences of Ukraine.

Habenicht, H. (1983). The anchoring effects - our present knowledge and its shortcomings. A keynote lecture. International Journal of Rock Mechanics and Mining Sciences \& Geomechanics Abstracts, 22(1), A34. https://doi.org/10.1016/0148-9062(85)92897-9

He, M., Gong, W., Wang, J., Qi, P., Tao, Z., Du, S., \& Peng, Y. (2014). Development of a novel energy-absorbing bolt with extraordinarily large elongation and constant resistance. International Journal of Rock Mechanics and Mining Sciences, (67), 29-42. https://doi.org/10.1016/j.ijrmms.2014.01.007

Hyett, A.J., Bawden, W.F., \& Reichert, R.D. (1992). The effect of rock mass confinement on the bond strength of fully grouted cable bolts. International Journal of Rock Mechanics and Mining Sciences \& Geomechanics Abstracts, 29(5), 503-524.

https://doi.org/10.1016/0148-9062(92)92634-o

Kolmogorov, A.N., \& Fomin, S.V. (1957). Elements of the theory of functions and functional analysis. Volume 1: Metric and normed spaces. Wisconsin, United States: Graylock Press.

Korzeniowski, W., Skrzypkowski, K., \& Zagórski, K. (2017). Reinforcement of underground excavation with expansion shell rock bolt equipped with deformable component. Studia Geotechnica et Mechanica, 39(1), 39-52. https://doi.org/10.1515/sgem-2017-0004

Li, C., \& Håkansson, U. (2018). Performance of the Swellex bolt in hard and soft rocks. Rock Support and Reinforcement Practice in Mining, 103-108.

https://doi.org/10.1201/9780203740460-9
Li, C.C. (2011). Performance of d-bolts under static loading. Rock Mechanics and Rock Engineering, 45(2), 183-192. https://doi.org/10.1007/s00603-011-0198-6

Li, C.C., Stjern, G., \& Myrvang, A. (2014). A review on the performance of conventional and energy-absorbing rockbolts. Journal of Rock Mechanics and Geotechnical Engineering, 6(4), 315-327. https://doi.org/10.1016/j.jrmge.2013.12.008

Nilsen, B., \& Palmstrom, A. (2000). Engineering geology and rock engineering. Handbook 2. Oslo, Norway: Norwegian Group for Rock Mechanics.

Pells, P.J. (2002). Developments in the design of tunnels and caverns in the Triassic rocks of the Sydney region. International Journal of Rock Mechanics and Mining Sciences, $39(5), 569-587$. https://doi.org/10.1016/s1365-1609(02)00058-8

Sakhno, I., Sakhno, S., Kurdiumow, D., \& Shvets, I. (2018). Studies of new nonadhesive anchoring. Mining of Mineral Deposits, 12(2), 85-94. https://doi.org/10.15407/mining12.02.085

Sakhno, I.G., \& Molodetsky, A.V. (2013). Laboratory studies of the dynamics of growth of self-expansion pressure of non-explosive destructive mixture in typical deformation modes. Ground Control in Mining, (20-21), 3-17.

Satola, I., \& Hakala, M. (2001). Corrosion-protected cable bolts in long-term reinforcement. Proceedings of EUROCK 2001 Symposium on Rock Mechanics, 377-382.

Wen, Z.J. (2010). Study of stress features of fully grouted prestressed anchors. Rock and Soil Mechanics, (31), 177-181.

Windsor, C. (1997). Rock reinforcement systems. International Journal of Rock Mechanics and Mining Science \& Geomechanics Abstracts, 34(6), 919-951. https://doi.org/10.1016/s0148-9062(97)00268-4

Windsor, C.R., \& Thompson, A.G. (1993). Rock reinforcement technology, testing, design and evaluation. Excavation, Support and Monitoring, 451-484.

https://doi.org/10.1016/b978-0-08-042067-7.50023-4

Yokota, Y., Zhao, Z., Nie, W., Date, K., Iwano, K., \& Okada, Y. (2018). Experimental and numerical study on the interface behaviour between the rock bolt and bond material. Rock Mechanics and Rock Engineering, 52(3), 869-879. https://doi.org/10.1007/s00603-018-1629-4

\section{ЛАБОРАТОРНІ ДОСЛІДЖЕННЯ ЗАКРІПЛЕННЯ АНКЕРНИХ БОЛТІВ СУМІШАМИ, ЩО САМОРОЗШИРЮЮТЬСЯ}

\section{I. Сахно, С. Сахно, О. Ісаєнков, Д. Курдюмов}

Мета. Дослідження параметрів нового способу закріплення анкерних болтів неадгезійними сумішами, які при твердінні розширюються з розвитком високих тисків розширення.

Методика. Дослідження зусилля закріплення анкерів сумішами, що саморозширюються, були проведені в лабораторних умовах у натуральному масштабі методом вдавлювання. Породний масив моделювався бетоном, залитим у пластикову та металеву опалубку, і сталевими трубами. Останні моделювали умови максимальної жорсткості. Анкерні болти імітувались відрізками арматурної сталі. В дослідженнях змінювали діаметр болтів від 8 до 32 мм, діаметр шпурів - від 26 до 43 мм. Тестування проводилося на гідравлічному 50-тонному пресі. Результати тестування були використані для отримання регресійних залежностей зусилля закріплення анкерів при різних співвідношеннях діаметру анкера та діаметру шпуру і глибині інкапсуляції. Шахтні польові дослідження зусилля закріплення анкерів Rockbolt System AG типу J64-27 при укріпленні камери 1 горизонту 3 ш. Величка (Польща) проводились методом статичного витягування болтів. Гідравлічний прилад для витягування було обладнано датчиком ZEPWN CL $18 \mathrm{~T}$ і реєстратором CL 162z-DW.

Результати. Експериментально доведено, що анкерні болти, закріплені сумішами, що саморозширюються при гідратаційному твердінні, мають механізм роботи, близький до сучасних енерго-абсорбуючих болтів. Визначено діапазон співвідношення діаметра анкеру до діаметра шпуру, в якому досягається максимальне зусилля закріплення болтів сумішами, що розширюються. Встановлено функціональний зв'язок між зусиллям закріплення анкерів сумішами, що розширюються, і діаметрами шпуру та анкера. Встановлено лінійний зв'язок між глибиною інкапсуляції й несучою здатністю анкера.

Наукова новизна. Розвинута нова концепція закріплення анкерних болтів неадгезійним способом за рахунок квазістатичного затиснення їх між стінками шпуру, яке відбувається у результаті гідратаційного самороз- 
ширення сумішей, що здатні досягати тисків 30 - 50 МПа в умовах нульових деформацій. Встановлено закономірності змінення зусилля закріплення болтів наведеним способом від геометричних параметрів системи “анкер - закріплююча суміш - масив”.

Практична значимість. Результати можуть використовуватися для розрахунку параметрів анкерного кріплення $з$ високою несучою здатністю в умовах великих деформацій контуру виробки. Запропонований спосіб кріплення може бути реалізований у гірничих виробках шахт.

Ключові слова: анкер, фіксачія анкерів, адгезія, гірські породи, напруження

\section{ЛАБОРАТОРНЫЕ ИССЛЕДОВАНИЯ ЗАКРЕПЛЕНИЯ АНКЕРНЫХ БОЛТОВ САМОРАСШИРЯЮЩИМИСЯ СМЕЯМИ}

\section{И. Сахно, С. Сахно, А. Исаенков, Д. Курдюмов}

Цель. Исследование параметров нового способа закрепления анкерных болтов неадгезионными смесями, которые при твердении расширяются с развитием высоких давлений расширения.

Методика. Исследования усилия закрепления анкеров расширяющимися смесями были проведены в лабораторных условиях в натуральном масштабе методом вдавливания. Породный массив моделировался бетоном, залитым в пластиковую и металлическую опалубку, и стальными трубами. Последние моделировали условия максимальной жесткости. Анкерные болты имитировались отрезками арматурной стали. В исследованиях изменяли диаметр болтов от 8 до 32 мм, диаметр шпуров - от 26 до 43 мм. Тестирование проводилось на гидравлическом 50-тонном прессе Результаты тестирования были использованы для получения регрессионных зависимостей усилия закрепления анкеров при различных соотношениях диаметра анкера и диаметра шпура и глубине инкапсуляции. Шахтные полевые исследования усилия закрепления анкеров Rockbolt System AG типа J64-27 при укреплении камеры 1 горизонта 3 ш. Величка (Польша) проводились методом статического вытягивания болтов. Гидравлический прибор был оборудован датчиком ZEPWN CL 18T и регистратором CL 162z-DW.

Результаты. Экспериментально доказано, что анкерные болты, закрепленные расширяющимися при гидратационном твердении смесями, имеют механизм работы, близкий к современным энерго-абсорбирующим болтам. Определен диапазон соотношения диаметра анкера к диаметру шпура, при котором достигается максимальное усилие закрепления болтов расширяющимися смесями. Установлена функциональная связь между усилием закрепления анкеров расширяющимися смесями и диаметрами шпура и анкера. Установлена линейная связь между глубиной инкапсуляции и несущей способностью анкера.

Научная новизна. Развита новая концепция закрепления анкерных болтов неадгезионным способом за счет квазистатического зажатия их между стенками шпура, которое происходит в результате гидратационного саморасширения смесей, которые могут достигать давлений 30 - 50 МПа в условиях нулевых деформаций. Установлены закономерности изменения усилия закрепления болтов приведенным способом от геометрических параметров системы “анкер - закрепляющая смесь - массив”.

Практическая значимость. Результаты могут использоваться для расчета параметров анкерного крепления с высокой несущей способностью в условиях больших деформаций контура выработки. Предложенный способ крепления может быть реализован в горных выработках шахт.

Ключевые слова: анкер, фиксация анкеров, адгезия, горные породы, напряжения

\section{ARTICLE INFO}

Received: 16 October 2018

Accepted: 22 March 2019

Available online: 8 April 2019

\section{ABOUT AUTHORS}

Ivan Sakhno, Doctor of Technical Sciences, Professor of the Department of Mineral Deposits, Donetsk National Technical University, 2 Shybankova Ave., 85300, Pokrovsk, Ukraine. E-mail: sahnohuan@gmail.com

Svitlana Sakhno, Candidate of Technical Sciences, Senior Instructor of the Geological Exploration and Enrichment, Donetsk National Technical University, 2 Shybankova Ave., 85300, Pokrovsk, Ukraine. E-mail: svitlana.sakhno@donntu.edu.ua

Oleksandr Isaienkov, Candidate of Technical Sciences, Senior Lecturer of the Department of Geotechnology and Safety, Industrial Institute of the Donetsk National Technical University, 2 Shybankova Ave., 85300, Pokrovsk, Ukraine. Email: alex is@ukr.net

Dmytro Kurdiumow, Master of Engineering, Company of Mining and High-Altitude Work “AMC”, 10/2 Danilowicza St, 32-020, Wieliczka, Poland. E-mail: kurddm@gmail.com 